\title{
CO Hydrogenation over Transition Metals (Fe, Co, or Ni) Modified $\mathrm{K} / \mathrm{Mo}_{2} \mathrm{C}$ Catalysts
}

\author{
Minglin Xiang and Juan Zou \\ Hunan Changling Petrochemical S\&T Developing Co. Ltd., Yueyang 414012, China \\ Correspondence should be addressed to Minglin Xiang; xiangml@sxicc.ac.cn
}

Received 3 May 2013; Accepted 26 July 2013

Academic Editor: Sankaranarayana Pillai Shylesh

Copyright (C) 2013 M. Xiang and J. Zou. This is an open access article distributed under the Creative Commons Attribution License, which permits unrestricted use, distribution, and reproduction in any medium, provided the original work is properly cited.

\begin{abstract}
Transition metals ( $\mathrm{Fe}, \mathrm{Co}$, or $\mathrm{Ni}$ ) modified $\mathrm{K} / \mathrm{Mo}_{2} \mathrm{C}$ catalysts were prepared and investigated as catalysts for $\mathrm{CO}$ hydrogenation. The addition of $\mathrm{Fe}, \mathrm{Co}$, or $\mathrm{Ni}$ to $\mathrm{K} / \mathrm{Mo}_{2} \mathrm{C}$ catalyst led to a sharp increase in both the activity and selectivity of $\mathrm{C}_{2}{ }^{+} \mathrm{OH}$, but the promotion effects were quite different and followed the sequence: $\mathrm{Ni}>\mathrm{Co}>\mathrm{Fe}$ for the activity and $\mathrm{Fe}>\mathrm{Co}>\mathrm{Ni}$ for the alcohol selectivity. For the products distributions, it also displayed some differences; Co promoter showed much higher $\mathrm{C}_{5}{ }^{+}$hydrocarbon selectivity than Fe or Ni promoter, but Fe or Co promoter gave lower methane selectivity than Ni promoter, and Fe promoter showed the highest $\mathrm{C}_{2}=\mathrm{C}_{4}=$ selectivity.
\end{abstract}

\section{Introduction}

The production of fuels from coal via syngas is one of the most industrial challenges for near future. As for Fischer-Tropsch reaction, reaction proceeds on transition metal supported catalysts, the catalysts currently investigated being $\mathrm{Co}, \mathrm{Fe}$, or $\mathrm{Ru}$ supported on oxides, such as $\mathrm{Al}_{2} \mathrm{O}_{3}, \mathrm{SiO}_{2}, \mathrm{TiO}_{2}$, and $\mathrm{ZrO}_{2}$ [1-3]. However, the application of such an attractive synthesis still suffers from the lack of high performance catalysts. Thus, great efforts are still being made to improve both activity and selectivity of catalysts. Since 1973, when Levy and Boudart [4] reported that WC displayed reactivity similar to Pt for hydrogenation reactions, there has been considerable interest in the catalytic properties of metal carbides, particularly of the group VI transition metals. Synthesis of hydrocarbons from CO hydrogenation over Co or Ru promoted molybdenum carbides has been evidenced by Griboval-Constant et al. [5], and the results reveal that molybdenum carbide gives light hydrocarbons and alcohols; the addition of $\mathrm{Ru}$ decreases the alcohol production yet $\mathrm{Co}$ increases formation of heavy hydrocarbons.

As reported elsewhere [6], promotion of molybdenum carbide by potassium has been found to greatly enhance the selectivity to alcohols. For $\mathrm{MoS}_{2}$-based catalysts, the addition of transition metals, such as $\mathrm{Co}, \mathrm{Ni}, \mathrm{Rh}$, and $\mathrm{Pd}$, is found to be able to improve the catalytic activity and selectivity of $\mathrm{C}_{2}{ }^{+}$alcohols [7-9]. In this regard, it also can be speculated that the transition metals may have positive effect on both $\mathrm{C}_{2}{ }^{+}$alcohols and heavy hydrocarbons formation from CO hydrogenation over $\mathrm{Mo}_{2} \mathrm{C}$-based catalysts, and still much less information is available.

Thus, the aim of this work is to study the influence of addition of transition metals, such as $\mathrm{Fe}, \mathrm{Co}$, or $\mathrm{Ni}$, on $\mathrm{K} / \mathrm{Mo}_{2} \mathrm{C}$ catalyst in terms of catalytic activity and selectivity in $\mathrm{CO}$ hydrogenation reaction.

\section{Experimental}

2.1. Sample Preparation. The molybdenum carbide was prepared through temperature-programmed-reaction (TPRe) method, and it could be found elsewhere [10]. In detail, the $\mathrm{Mo}_{2} \mathrm{C}$ and $\mathrm{M}-\mathrm{Mo}_{2} \mathrm{C}(\mathrm{M}=\mathrm{Fe}, \mathrm{Co}, \mathrm{Ni})$ with the hexagonal close packed (HCP) structure were prepared by direct carburization of the $\mathrm{MoO}_{3}$ and $\mathrm{MMo}$ oxide precursors, respectively. The oxide precursors for bimetallic carbides were prepared by mechanically mixing a stoichiometric amount of the corresponding nitrate, for example, $\mathrm{Fe}\left(\mathrm{NO}_{3}\right)_{3} \cdot 9 \mathrm{H}_{2} \mathrm{O}, \mathrm{Co}\left(\mathrm{NO}_{3}\right)_{2} \cdot 6 \mathrm{H}_{2} \mathrm{O}$ or $\mathrm{Ni}\left(\mathrm{NO}_{3}\right)_{2} \cdot 6 \mathrm{H}_{2} \mathrm{O}$ with $\left(\mathrm{NH}_{4}\right)_{6} \mathrm{Mo}_{7} \mathrm{O}_{24} \cdot 4 \mathrm{H}_{2} \mathrm{O}$; the mixture was then calcined at 
$673 \mathrm{~K}$ for several hours. TPRe was carried out under atmospheric pressure in a flow of $\mathrm{CH}_{4} / \mathrm{H}_{2}$ gas mixture. The temperature was linearly increased from room temperature (RT) to $973 \mathrm{~K}$, where it was maintained for additional hours. Then the samples were quenched to RT and gradually passivated with $\mathrm{O}_{2} / \mathrm{N}_{2}$ before exposure to air. $\mathrm{K}_{2} \mathrm{CO}_{3}$ modification was accomplished by a postdoping procedure after synthesis of the final carbide [6].

2.2. Characterization Methods. X-ray powder diffraction (XRD) patterns of the tested catalysts were obtained on a Rigaku D/Max 2500 powder diffractometer using $\mathrm{Cu} \mathrm{K} \alpha$ radiation as the $\mathrm{X}$-ray source.

XPS was recorded on a VG MultiLab 2000 spectrometer using an $\mathrm{Mg} \mathrm{K} \alpha \mathrm{X}$-ray source. The catalysts were pretreated at $633 \mathrm{~K}$ under syngas $\left(\mathrm{H}_{2} / \mathrm{CO}=1.0\right)$ for several hours then quenched to RT under $\mathrm{N}_{2}$ atmosphere (see Figure 3). The catalyst was removed from the reactor under $\mathrm{N}_{2}$ atmosphere in a glovebox and secured onto the XPS holder with carbon tape for testing.

2.3. CO Hydrogenation. CO hydrogenation was carried out using a stainless fixed-bed reactor with $4 \mathrm{~mL}$ (about 6 gram) of catalyst. The effluents were analyzed by $1790-\mathrm{GC}$ and among these $\mathrm{H}_{2}, \mathrm{CO}, \mathrm{CH}_{4}$, and $\mathrm{CO}_{2}$ were analyzed by thermal conductivity detector (TCD) equipped with a TDX-101 column; $\mathrm{C}_{1}-\mathrm{C}_{4}$ alkanes were detected by flame ionization detector (FID) with a Chromosorb 101 column; $\mathrm{C}_{1}-\mathrm{C}_{4}$ alkenes were detected by FID with a packed column $\mathrm{C}-18$; the water and methanol in liquids were also detected by TCD with a GDX-401 column; the alcohols and hydrocarbons were analyzed by FID with a Porapack-Q column. $\mathrm{C}_{5}{ }^{+}$ hydrocarbons were detected by FID with a capillary column. The mass balance was based on carbon, and the error of the balance of oxygen and hydrogen was within $5 \%$.

\section{Results and Discussion}

\subsection{Catalytic Performances}

3.1.1. Catalytic Performance of $\mathrm{K} / \mathrm{Mo}_{2} \mathrm{C}$. The results of $\mathrm{CO}$ hydrogenation over $\mathrm{K} / \mathrm{Mo}_{2} \mathrm{C}$ catalyst are listed in Table 1. Clearly, the catalytic performance was readily affected by the reaction conditions employed. As the pressure enhanced, both the CO conversion and hydrocarbon selectivity increased, whereas the alcohols selectivity rapidly reduced. According to the literature [11], the higher pressure led to higher alcohol selectivity. However, it was noted that the low pressure favored the alcohol synthesis over $\mathrm{K} / \mathrm{Mo}_{2} \mathrm{C}$ catalyst. In all cases, $\mathrm{K} / \mathrm{Mo}_{2} \mathrm{C}$ catalyst presented almost a constant carbon dioxide yield $(\sim 35 \%)$, which reflected high watergas shift activities of molybdenum carbide as frequently reported by others $[12,13]$. As the pressure increased, the distribution of alcohols nearly remained the same, but the hydrocarbon distribution changed remarkably, the methane was suppressed, and $\mathrm{C}_{5}{ }^{+}$hydrocarbons was formed. Anyway, the methane selectivity was very high, which might be another feature of $\mathrm{Mo}_{2} \mathrm{C}$-based catalyst as reported elsewhere [10].

\subsubsection{Catalytic Performance of Transition Metals Modified} $\mathrm{K} / \mathrm{Mo}_{2} \mathrm{C}$. The catalytic performance of $\mathrm{CO}$ hydrogenation over transition metals modified $\mathrm{K} / \mathrm{Mo}_{2} \mathrm{C}$ catalyst is shown in Table 2. It can be seen that $\mathrm{Fe}, \mathrm{Co}$, or Ni promoter induced similar trends in activity and products distribution over $\mathrm{K} / \mathrm{Mo}_{2} \mathrm{C}$ catalyst. An increase of pressure reduced the alcohol selectivity, whereas the hydrocarbon formation was greatly promoted. However, it was obvious to see that $\mathrm{Fe}, \mathrm{Co}$, or Ni promoter led to a sharp increase in both the activity and selectivity of $\mathrm{C}_{2}{ }^{+} \mathrm{OH}$. Compared with $\mathrm{K} / \mathrm{Mo}_{2} \mathrm{C}$ catalyst, the proportion of methanol was further suppressed, and $\mathrm{C}_{2}{ }^{+} \mathrm{OH}$ became the major alcohol product. This indicated that transition metals had strong ability to promote the carbon chain growth. Also, in $\mathrm{K} / \mathrm{Mo}_{2} \mathrm{C}$ catalyst modified by $\mathrm{Fe}, \mathrm{Co}$, or $\mathrm{Ni}$, the fraction of methane was decreased and the production of $\mathrm{C}_{5}{ }^{+}$hydrocarbons was greatly enhanced.

Undoubtedly, $\mathrm{Fe}, \mathrm{Co}$, or $\mathrm{Ni}$ had positive effect on catalytic performance of $\mathrm{CO}$ hydrogenation over $\mathrm{K} / \mathrm{Mo}_{2} \mathrm{C}$ catalyst; however, it also presented a different promoting effect (see Figure 1). Under the conditions of $613 \mathrm{~K}, 8.0 \mathrm{MPa}, \mathrm{H}_{2} / \mathrm{CO}=$ 1.0 , and $1000 \mathrm{~h}^{-1}, \mathrm{Ni}$ promoter showed the highest catalytic activity, but Fe promoter gave the highest alcohol selectivity. As a result, the promotion effects of transition metals were different and followed the sequence: $\mathrm{Ni}>\mathrm{Co}>\mathrm{Fe}$ for the activity and $\mathrm{Fe}>\mathrm{Co}>\mathrm{Ni}$ for the alcohol selectivity. For the products distributions, it also displayed some differences. Co promoter showed much higher $\mathrm{C}_{5}{ }^{+}$hydrocarbon selectivity than $\mathrm{Fe}$ or $\mathrm{Ni}$ promoter, but $\mathrm{Fe}$ or Co promoter gave lower methane selectivity than $\mathrm{Ni}$ promoter, which might be attributed to Ni that was an excellent methanation component. Among them, Fe promoter showed the highest $\mathrm{C}_{2}{ }{ }^{-}-\mathrm{C}_{4}=$ selectivity due to its strong ability of carbon chain propagation.

3.2. Structural Properties. The XRD patterns of the samples are shown in Figure 2; the as-prepared catalysts all had definitive phase of the $\beta-\mathrm{Mo}_{2} \mathrm{C}[6]\left(2 \theta=34.4^{\circ}, 38.0^{\circ}, 39.4^{\circ}, 52.1^{\circ}\right.$, $61.5^{\circ}, 69.6^{\circ}, 74.6^{\circ}$, and $75.6^{\circ}$ for $\beta-\mathrm{Mo}_{2} \mathrm{C}$ [100], [002], [101], [102], [110], [103], [112], and [201], resp.). When modified by $\mathrm{Ni}$, the diffraction peaks corresponding to the metallic $\mathrm{Ni}$ were detected $\left(2 \theta\right.$ values was at $44.5^{\circ}$ and $\left.51.3^{\circ}\right)[14,15]$. Modified by $\mathrm{Fe}$, the $\mathrm{Fe}_{3} \mathrm{C}$ or metallic Fe phase appeared at the $2 \theta$ value of $44.7^{\circ}$, which might be accounted for the promotional effect of Fe [16]. Also, modified by Co promoter, the signals at $42.6^{\circ}$ and $46.5^{\circ}$ might correspond to $\mathrm{Co}_{3} \mathrm{Mo}_{3} \mathrm{C}$, and weak signals at $44.2^{\circ}$ might correspond to $\mathrm{Co}_{2} \mathrm{C}[17,18]$, which ascribed to the strong synergistic effect of Co and Mo.

3.3. XPS Studies. In order to study the interaction between Mo and promoters, first the surface chemistry as well as electronic environment of $\mathrm{K} / \mathrm{Mo}_{2} \mathrm{C}$ catalyst was investigated. It showed the presence of Mo $3 \mathrm{~d}$ in several oxidation states located at $228.0 \mathrm{eV}, 231.5 \mathrm{eV}$, and $235.0 \mathrm{eV}$. According to the literature, the peak at about $228.2 \mathrm{eV}$ was unambiguously 


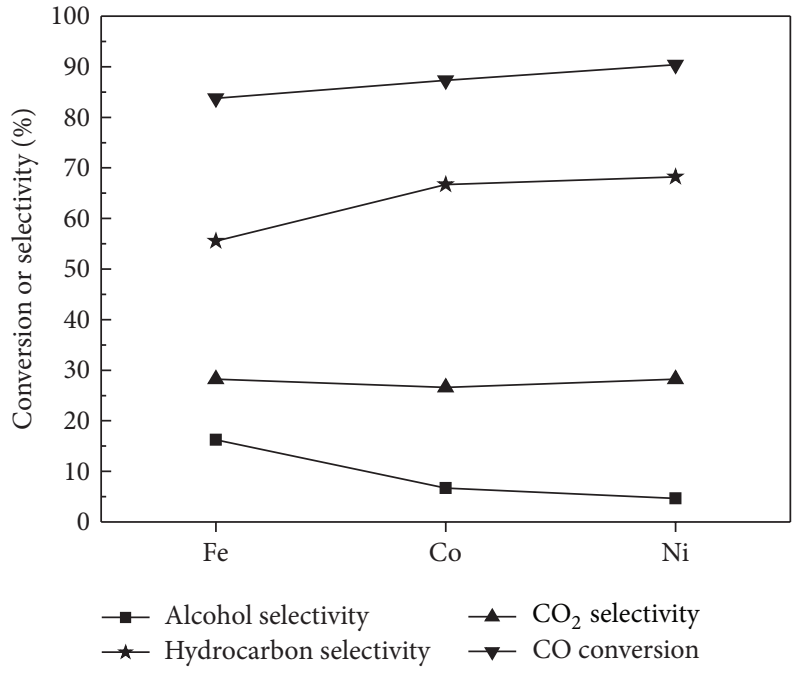

(a)

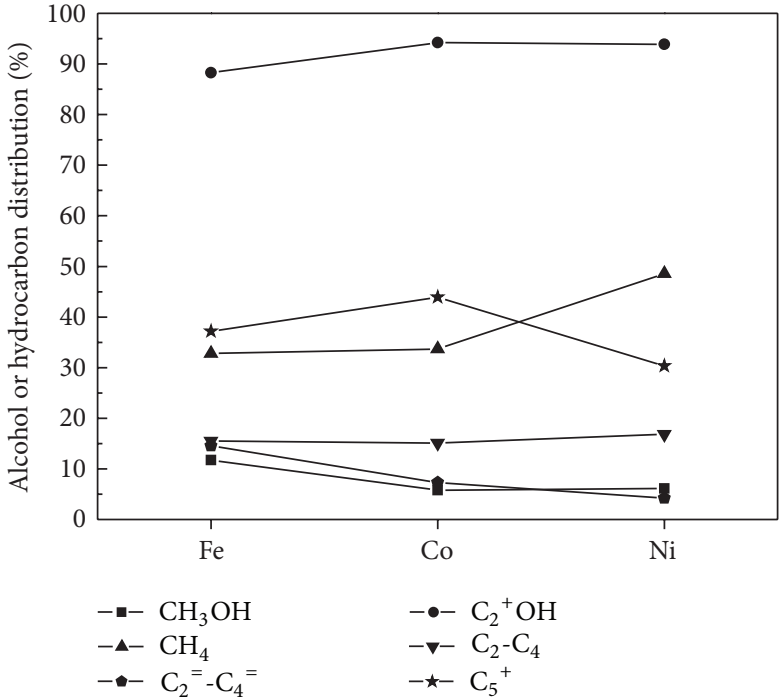

(b)

Figure 1: Fe, Co, and Ni promoter on the performance of $\mathrm{K} / \mathrm{Mo}_{2} \mathrm{C}\left(613 \mathrm{~K}, 8.0 \mathrm{MPa}, \mathrm{H}_{2} / \mathrm{CO}=1.0,1000 \mathrm{~h}^{-1}\right)$.

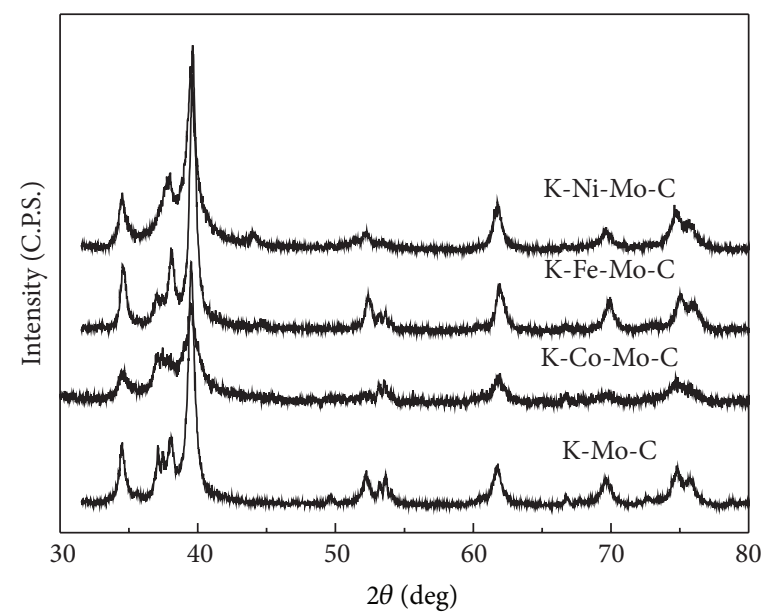

FIgURE 2: XRD patterns of transition metals modified $\mathrm{K} / \mathrm{Mo}_{2} \mathrm{C}$ catalyst.

TABLE 1: Catalytic performance of $\mathrm{K} / \mathrm{Mo}_{2} \mathrm{C}$ catalyst $\left(613 \mathrm{~K}, \mathrm{H}_{2} / \mathrm{CO}=1.0,1000 \mathrm{~h}^{-1}\right)$.

\begin{tabular}{|c|c|c|c|c|c|c|c|c|}
\hline \multirow{2}{*}{$P(\mathrm{MPa})$} & \multirow{2}{*}{ CO Conv. (\%) } & \multicolumn{3}{|c|}{ Selectivity (mol\%) } & \multicolumn{2}{|c|}{$\mathrm{ROH}$ distribution $(\mathrm{C} \%)$} & \multicolumn{2}{|c|}{$\mathrm{CHx}$ distribution $(\mathrm{C} \%)$} \\
\hline & & $\mathrm{ROH}$ & $\mathrm{CHx}$ & $\mathrm{CO}_{2}$ & $\mathrm{CH}_{3} \mathrm{OH}$ & $\mathrm{C}_{2}{ }^{+} \mathrm{OH}$ & $\mathrm{CH}_{4}$ & $\mathrm{C}_{5}^{+}$ \\
\hline 2.0 & 12.4 & 32.8 & 30.9 & 36.3 & 20.5 & 79.5 & 66.9 & 0 \\
\hline 4.0 & 19.0 & 23.4 & 40.2 & 36.4 & 17.0 & 83.0 & 65.9 & 0 \\
\hline 6.0 & 33.6 & 16.8 & 49.0 & 34.2 & 16.6 & 83.4 & 62.3 & 3.9 \\
\hline 8.0 & 53.1 & 12.0 & 52.8 & 35.2 & 18.9 & 81.1 & 59.5 & 9.1 \\
\hline
\end{tabular}

attributed to Mo atoms in the carbide form, metallic molybdenum being detected at about $227.2 \mathrm{eV}$ [19]; the peak at $235.0 \mathrm{eV}$ was attributed to $\mathrm{Mo}^{6+}$, which was characteristic of oxidized phases, resulting from the passivation step [20], and the peak at $231.5 \mathrm{eV}$ was probably attributed to $\mathrm{Mo}^{4+}$ and $\mathrm{Mo}^{5+}$ species. The $\mathrm{C}$ 1s spectrum primarily showed three peaks. The peak at $284.6 \mathrm{eV}$ was attributed to amorphous carbon as reported by several authors [21, 22]. The peak at $288.3 \mathrm{eV}$ was attributed to the carbon atoms involved in carbonate species such as $\mathrm{C}=\mathrm{O}$ or $\mathrm{C}-\mathrm{O}$ species and was due to contamination. Further investigation revealed that the weak signal at $283.3 \mathrm{eV}$ might correspond to a carbon bonded to a metal in a carbide form [21, 22]. Very likely due to the deposition of excess carbon in the form of coke, the signal of 


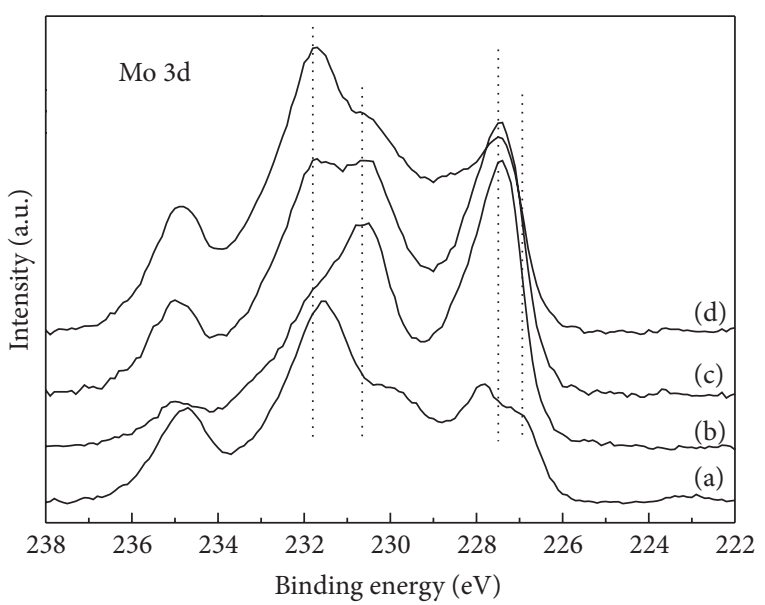

(a)

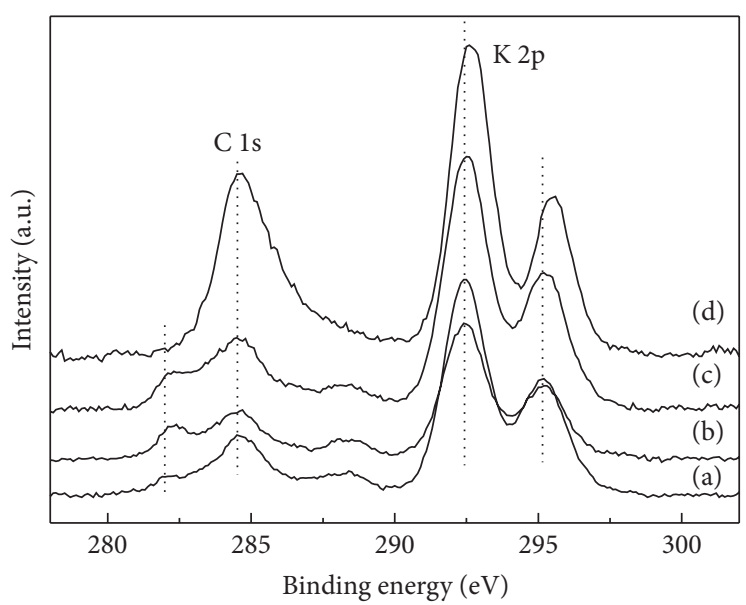

(b)

Figure 3: The Mo 3d, C 1s, and $\mathrm{K} 2 \mathrm{p}$ spectra of (a) $\mathrm{K} / \mathrm{Mo}_{2} \mathrm{C}$, (b) $\mathrm{K} / \mathrm{Fe}-\mathrm{Mo}_{2} \mathrm{C}$, (c) $\mathrm{K} / \mathrm{Co}-\mathrm{Mo}_{2} \mathrm{C}$, and (d) $\mathrm{K} / \mathrm{Ni}^{-}-\mathrm{Mo}_{2} \mathrm{C}$ pretreated by syngas at $633 \mathrm{~K}$.

TABLE 2: Catalytic performance of transition metals modified $\mathrm{K} / \mathrm{Mo}_{2} \mathrm{C}$ catalyst $\left(613 \mathrm{~K}, \mathrm{H}_{2} / \mathrm{CO}=1.0,1000 \mathrm{~h}^{-1}\right)$.

\begin{tabular}{|c|c|c|c|c|c|c|c|c|}
\hline \multirow{2}{*}{$P(\mathrm{MPa})$} & \multirow{2}{*}{ CO Conv. (\%) } & \multicolumn{3}{|c|}{ Selectivity (mol\%) } & \multicolumn{2}{|c|}{ ROH distribution (C\%) } & \multicolumn{2}{|c|}{$\mathrm{CHx}$ distribution $(\mathrm{C} \%)$} \\
\hline & & $\mathrm{ROH}$ & $\mathrm{CHx}$ & $\mathrm{CO}_{2}$ & $\mathrm{CH}_{3} \mathrm{OH}$ & $\mathrm{C}_{2}^{+} \mathrm{OH}$ & $\mathrm{CH}_{4}$ & $\mathrm{C}_{5}^{+}$ \\
\hline \multicolumn{9}{|c|}{$\mathrm{K} / \mathrm{Fe}-\mathrm{Mo}_{2} \mathrm{C}$} \\
\hline 2.0 & 15.0 & 23.4 & 52.8 & 23.8 & 8.8 & 91.2 & 34.3 & 6.8 \\
\hline 4.0 & 49.8 & 19.5 & 42.7 & 37.8 & 8.9 & 91.1 & 36.3 & 20.1 \\
\hline 6.0 & 68.0 & 15.3 & 48.0 & 36.8 & 11.5 & 88.5 & 35.6 & 20.8 \\
\hline 8.0 & 83.8 & 16.2 & 55.5 & 28.3 & 11.7 & 88.3 & 32.8 & 37.2 \\
\hline \multicolumn{9}{|c|}{$\mathrm{K} / \mathrm{Co}-\mathrm{Mo}_{2} \mathrm{C}$} \\
\hline 2.0 & 51.1 & 11.7 & 55.0 & 33.3 & 7.5 & 92.5 & 32.9 & 30.4 \\
\hline 4.0 & 86.3 & 7.4 & 59.0 & 33.6 & 6.9 & 93.1 & 30.4 & 40.0 \\
\hline 6.0 & 89.4 & 8.8 & 61.6 & 29.6 & 9.3 & 90.7 & 35.5 & 38.9 \\
\hline 8.0 & 87.3 & 6.7 & 66.7 & 26.6 & 5.8 & 94.2 & 33.7 & 43.9 \\
\hline \multicolumn{9}{|c|}{$\mathrm{K} / \mathrm{Ni}-\mathrm{Mo}_{2} \mathrm{C}$} \\
\hline 2.0 & 59.2 & 11.1 & 57.3 & 31.6 & 6.2 & 93.8 & 47.6 & 21.96 \\
\hline 4.0 & 84.9 & 8.4 & 59.2 & 32.4 & 7.1 & 92.9 & 48.3 & 20.44 \\
\hline 6.0 & 89.9 & 8.9 & 61.2 & 29.9 & 6.6 & 93.4 & 50.5 & 23.12 \\
\hline 8.0 & 90.4 & 4.6 & 68.2 & 27.2 & 6.1 & 93.9 & 48.6 & 30.34 \\
\hline
\end{tabular}

$\mathrm{C} 1 \mathrm{~s}$ at $284.6 \mathrm{eV}$ was very strong. Thus, the peak for the carbon atoms in the carbide form was very weak.

Modified by transition metals (Fe, Co, or Ni), dramatic changes of the Mo 3d spectra took place compared to those of $\mathrm{K} / \mathrm{Mo}_{2} \mathrm{C}$ catalyst, and the signals assigned to low value of Mo became strong, but the middle value of Mo showed a slight decrease. The electron interaction between transition metals and molybdenum resulted in the increase of the d-orbital occupation in molybdenum atoms, which further promoted the intrinsic activity. Laniecki et al. reported that the presence of transition metals enhanced the reducibility of Mo species and was responsible for the improvement of the catalytic performance [23]. However, the $\mathrm{Fe}, \mathrm{Co}$, or $\mathrm{Ni}$ promoter displayed a different promotional effect. Modified by Fe, the signals at about $228.0 \mathrm{eV}$ and $230.7 \mathrm{eV}$ were the strongest, whereas modified by $\mathrm{Ni}$, the signal at about $231.8 \mathrm{eV}$ ascribed to middle value of Mo was the strongest. Also, from the $\mathrm{C} 1 \mathrm{~s}$ spectra, it was noted that the intensity of peaks at $284.6 \mathrm{eV}$ was dramatically strong when $\mathrm{K} / \mathrm{Mo}_{2} \mathrm{C}$ catalyst modified by $\mathrm{Ni}$, which revealed the ability of $\mathrm{CO}$ dissociation that became strong owing to the $\mathrm{Ni}$ was a methanation promoter. These different changes might be related to the different interactions between transition metals and Mo, which further influenced the catalytic performances of $\mathrm{CO}$ hydrogenation over the $\mathrm{K} / \mathrm{Mo}_{2} \mathrm{C}$ catalyst.

\section{Conclusions}

$\mathrm{Fe}, \mathrm{Co}$, or $\mathrm{Ni}$ had a positive effect on catalytic activity of $\mathrm{CO}$ hydrogenation over $\mathrm{K} / \mathrm{Mo}_{2} \mathrm{C}$ catalyst, and they made 
the products over $\mathrm{K} / \mathrm{Mo}_{2} \mathrm{C}$ shift remarkably from methanol to $\mathrm{C}_{2}{ }^{+} \mathrm{OH}$, and from methane to $\mathrm{C}_{5}{ }^{+}$hydrocarbons at the expense of alcohol selectivity. However, $\mathrm{Fe}, \mathrm{Co}$, or Ni also displayed a different promoting effect on catalytic performance of $\mathrm{CO}$ hydrogenation. In terms of characterization results, the different interactions between transition metals ( $\mathrm{Fe}, \mathrm{Co}$, or $\mathrm{Ni}$ ) and Mo might account for the different catalytic performances over $\mathrm{K} / \mathrm{Mo}_{2} \mathrm{C}$ catalyst.

\section{References}

[1] H. Abrevaya, M. J. Cohn, W. M. Targos, and H. J. Robota, "Structure sensitive reactions over supported ruthenium catalysts during Fischer-Tropsch synthesis," Catalysis Letters, vol. 7, no. 1-4, pp. 183-195, 1990.

[2] D. Vanhove, Z. Zhuyong, L. Makambo, and M. Blanchard, "Hydrocarbon selectivity in fischer-tropsch synthesis in relation to textural properties of supported cobalt catalysts," Applied Catalysis, vol. 9, no. 3, pp. 327-342, 1984.

[3] E. Iglesia, S. C. Reyes, R. J. Madon, and S. L. Soled, "Selectivity control and catalyst design in the Fischer-Tropsch synthesis: sites, pellets, and reactors," Advances in Catalysis, vol. 39, pp. 221-302, 1993.

[4] R. B. Levy and M. Boudart, "Platinum-like behavior of tungsten carbide in surface catalysis," Science, vol. 181, no. 4099, pp. 547$549,1973$.

[5] A. Griboval-Constant, J.-M. Giraudon, G. Leclercq, and L. Leclercq, "Catalytic behaviour of cobalt or ruthenium supported molybdenum carbide catalysts for FT reaction," Applied Catalysis A, vol. 260, no. 1, pp. 35-45, 2004.

[6] M. Xiang, D. Li, W. Li, B. Zhong, and Y. Sun, "Performances of mixed alcohols synthesis over potassium promoted molybdenum carbides," Fuel, vol. 85, no. 17-18, pp. 2662-2665, 2006.

[7] Z. R. Li, Y. L. Fu, and M. Jiang, "Structures and performance of Pd-Mo-K/ $/ \mathrm{Al}_{2} \mathrm{O}_{3}$ catalysts used for mixed alcohol synthesis from synthesis gas," Catalysis Letters, vol. 65, pp. 43-48, 2000.

[8] Z.-R. Li, Y.-L. Fu, and M. Jiang, "Structures and performance of Rh-Mo- $\mathrm{K} / \mathrm{Al}_{2} \mathrm{O}_{3}$ catalysts used for mixed alcohol synthesis from synthesis gas," Applied Catalysis A, vol. 187, no. 2, pp. 187$198,1999$.

[9] E. C. Alyea, D. He, and J. Wang, "Alcohol synthesis from syngas. I. Performance of alkali-promoted Ni-Mo(MOVS) catalysts," Applied Catalysis A, General, vol. 104, no. 1, pp. 77-85, 1993.

[10] M. Xiang, D. Li, H. Xiao et al., "Synthesis of higher alcohols from syngas over Fischer-Tropsch elements modified $\mathrm{K} / \beta$ $\mathrm{Mo}_{2} \mathrm{C}$ catalysts," Fuel, vol. 87, pp. 599-603, 2008.

[11] D. Li, Study of nickel promoted $\mathrm{K}_{2} \mathrm{CO}_{3} / \mathrm{MOS}_{2}$ catalysts for higher alcohols synthesis from $\mathrm{CO} / \mathrm{H}_{2}$ [Ph.D. Dissertation], Institute of Coal Chemistry, Chinese Academy of Sciences, 2004.

[12] M. Saito and R. B. Anderson, "The activity of several molybdenum compounds for the methanation of CO," Journal of Catalysis, vol. 63, no. 2, pp. 438-446, 1980.

[13] I. Kijima and E. Miyazaki, "Catalysis by transition metal carbides: V. Kinetic measurements of hydrogenation of $\mathrm{CO}$ over $\mathrm{TaC}, \mathrm{TiC}$, and $\mathrm{Mo}_{2} \mathrm{C}$ catalysts," Journal of Catalysis, vol. 89, pp. 168-171, 1984.

[14] C. Liang, W. Ma, Z. Feng, and C. Li, "Activated carbon supported bimetallic CoMo carbides synthesized by carbothermal hydrogen reduction," Carbon, vol. 41, no. 9, pp. 1833-1839, 2003.
[15] J. Bao, Y. Fu, Z. Sun, and C. Gao, "A highly active K-Co-Mo/C catalyst for mixed alcohol synthesis from $\mathrm{CO}+\mathrm{H} 2$," Chemical Communications, vol. 9, no. 6, pp. 746-747, 2003.

[16] M. Xiang, J. Zou, Q. Li, and X. She, "Catalytic performance of iron carbide for carbon monoxide hydrogenation," Journal of Natural Gas Chemistry, vol. 19, no. 5, pp. 468-470, 2010.

[17] M. Xiang, D. Li, W. Li, B. Zhong, and Y. Sun, "Synthesis of higher alcohols from syngas over $\mathrm{K} / \mathrm{Co} / \beta-\mathrm{Mo}_{2} \mathrm{C}$ catalysts," Catalysis Communications, vol. 8, no. 3, pp. 503-507, 2007.

[18] L. J. E. Hofer and W. C. Peebles, "X-ray diffraction studies of the action of carbon monoxide on cobalt-thoria-kieselguhr catalysts," Journal of the American Chemical Society, vol. 69, no. 10, pp. 2497-2500, 1947.

[19] K. Oshikawa, M. Nagai, and S. Omi, "Characterization of molybdenum carbides for methane reforming by TPR, XRD, and XPS," Journal of Physical Chemistry B, vol. 105, no. 38, pp. 91249131, 2001.

[20] T. P. St. Clair, S. T. Oyama, D. F. Cox et al., "Surface characterization of $\alpha-\mathrm{Mo}_{2} \mathrm{C}$ (0001)," Surface Science, vol. 426, no. 2, pp. 187198, 1999.

[21] P. Delporte, C. Pham-Huu, and M. J. Ledoux, "Effect of the reaction temperature and hydrocarbon partial pressure on the activity of carbon-modified $\mathrm{MoO}_{3}$ for n-hexane isomerization," Applied Catalysis A, vol. 149, no. 1, pp. 151-180, 1997.

[22] M. J. Ledoux, C. P. Huu, J. Guille, and H. Dunlop, "Compared activities of platinum and high specific surface area $\mathrm{Mo}_{2} \mathrm{C}$ and WC catalysts for reforming reactions. I. Catalyst activation and stabilization: reaction of n-hexane," Journal of Catalysis, vol. 134, no. 2, pp. 383-398, 1992.

[23] M. Łaniecki, M. Małecka-Grycz, and F. Domka, "Water-gas shift reaction over sulfided molybdenum catalysts I. Alumina, titania and zirconia-supported catalysts," Applied Catalysis A, vol. 196, no. 2, pp. 293-303, 2000. 

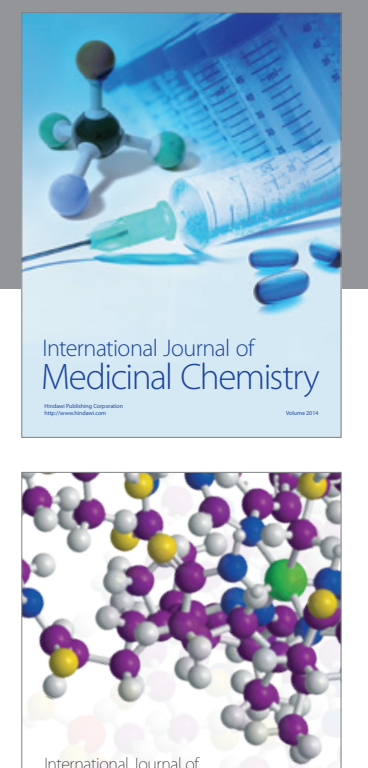

\section{Carbohydrate} Chemistry

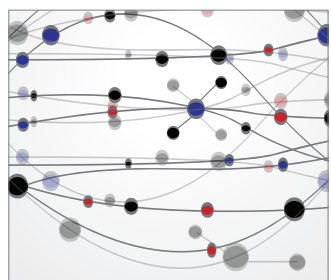

The Scientific World Journal
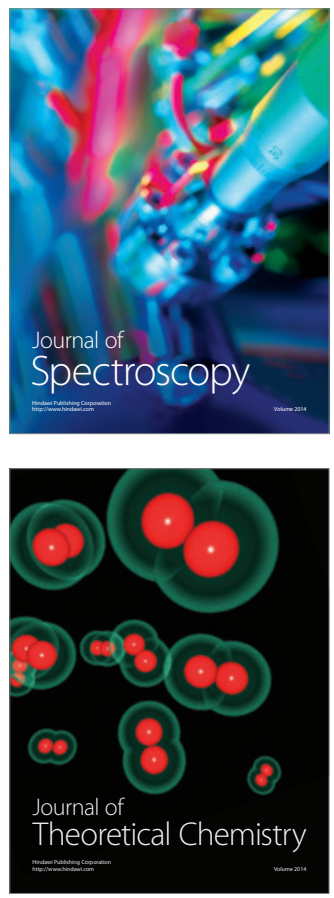
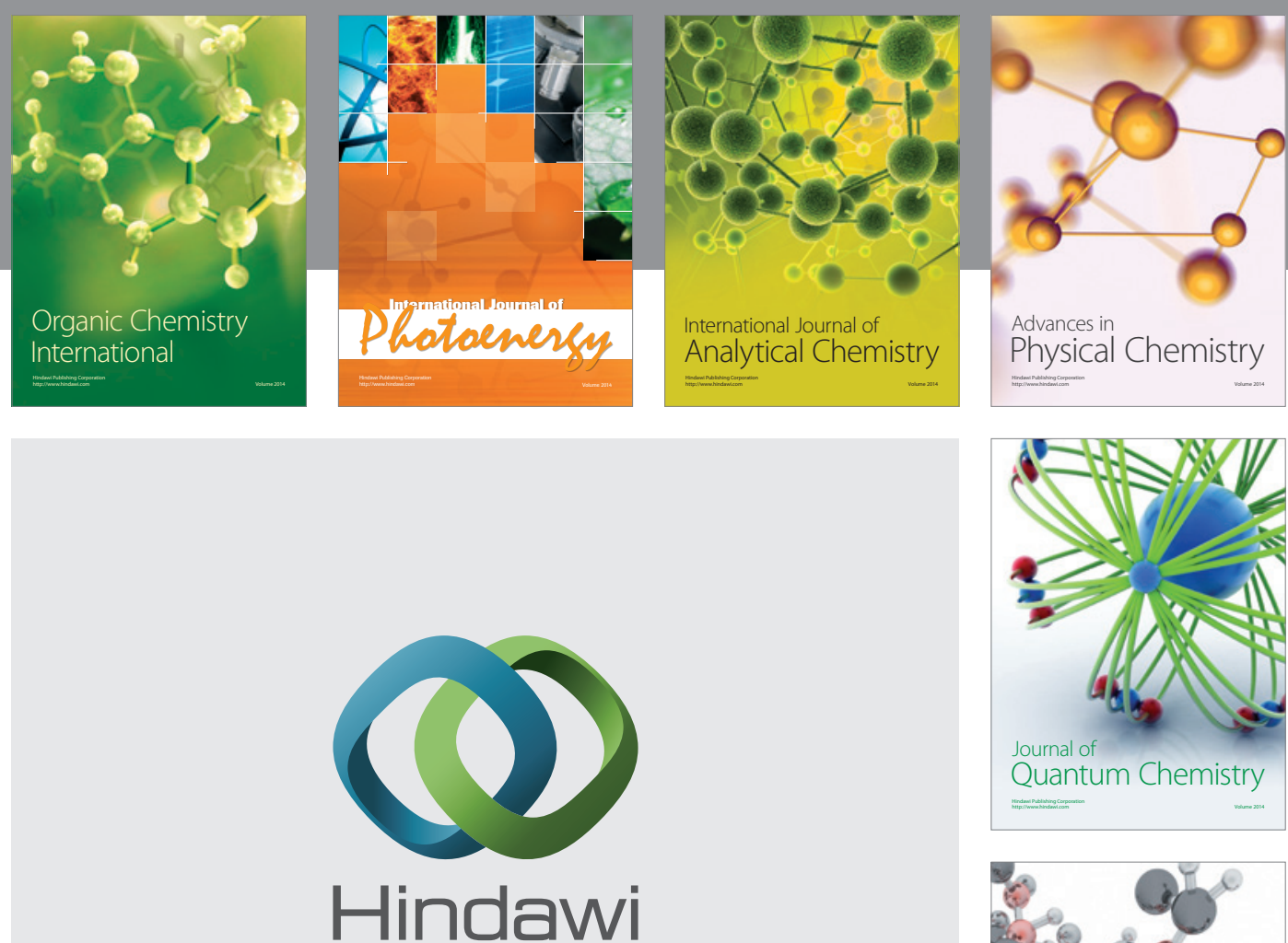

Submit your manuscripts at

http://www.hindawi.com

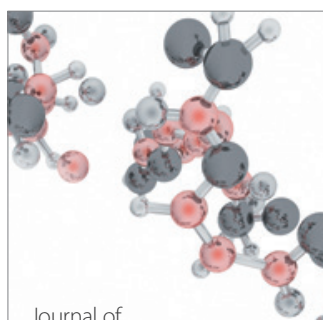

Analytical Methods

in Chemistry

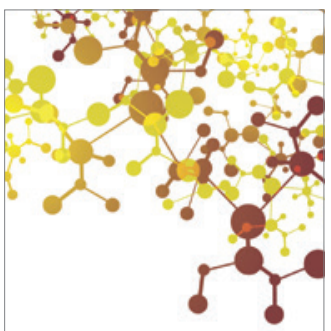

Journal of

Applied Chemistry

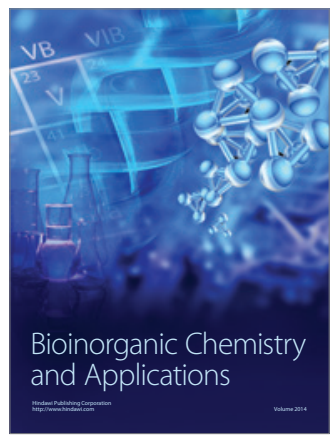

Inorganic Chemistry
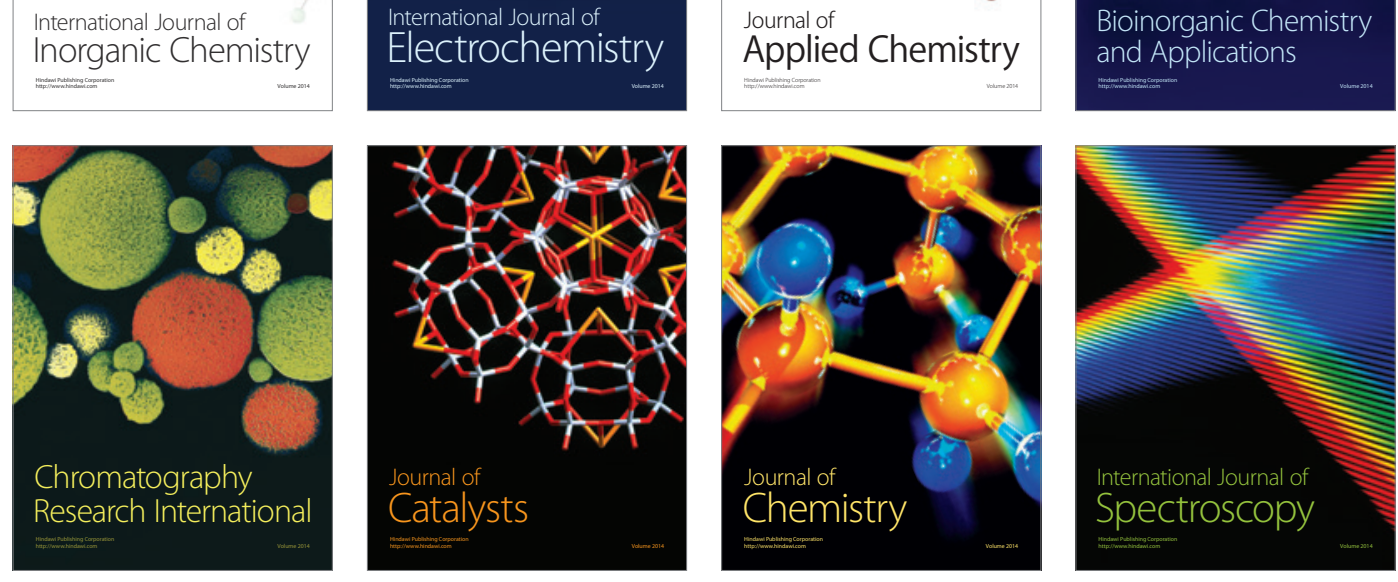